\title{
Hyperlinkkien funktiot ja kirjoittaja- ja lukijapositiot
}

\author{
ELINA VitikKa
}

Hyperlinkit ovat tyypillinen viittaamisen keino verkkoteksteissä (esim.Luzón 2009: 75; Puschmann 2013: 84). Tässä artikkelissa tarkastelen, miten hyperlinkkejä käytetään terveyden ja ravitsemuksen asiantuntijoiden kirjoittamissa yleistajuisissa ja tutkittuun tietoon perustuvissa blogiteksteissä. Tutkimuskysymykseni ovat seuraavat: 1) Minkälaisen kielellisen toiminnan osana hyperlinkit teksteissä ovat ja minkälaisia funktioita ne tässä toiminnassa saavat? 2) Minkälaisia kirjoittaja- ja lukijapositioita hyperlinkit blogiteksteille rakentavat? Tutkimukseni on jatkoa kotimaiselle dialogistiselle diskurssintutkimukselle (esim. Makkonen-Craig 2005; Juvonen 2014; Virtanen 2015) ja digitaalisen vuorovaikutuksen tutkimukselle (esim. Helasvuo, Johansson \& Tanskanen 2014) sekä kotimaiselle yleistajuisen tiedonkerronnan tutkimukselle, jota toistaiseksi on tehty lähinnä oppikirjoista (esim. Karvonen 1995; vrt. Strellman \& Vaattovaara toim. 2013).

Blogit ovat tänä päivänä tavallinen viestintämuoto sekä asiantuntijoille että maallikoille ja niin yksityishenkilöille kuin instituutioiden edustajillekin (esim. Kouper 2010; Luzón 2013; Mauranen 2013; ks. myös Rydenfelt 2016). Myös tutkijoita on kannustettu hyödyntämään blogia yleistajuisessa tiedonkerronnassaan (esim. Mauranen 2013: 8). Blogeja onkin kymmenen viime vuoden aikana tutkittu ahkerasti tiedonkerronnan välineenä (Mahrt \& Puschmann 2014: 2) ja myös siltä kannalta, miten hyperlinkkejä käytetään tiedeblogeissa (Luzón 2009, 2013). Lingvististä tutkimusta yleistajuisten tiedeblogien hyperlinkkeihin liittyvästä kielellisestä toiminnasta ja niihin kietoutuvista kirjoittaja- ja lukijapositioista ei kuitenkaan toistaiseksi ole tehty suomenkielisestä aineistosta - aukko, jota tämä artikkeli osaltaan paikkaa.

\section{Blogeista, hyperlinkeistä ja digitaalisesta viestinnästä}

Blogi on digitaalisen viestinnän ${ }^{1}$ muoto, jonka mahdollistaa Web 2.0:ksi kutsuttu internetin kehitysvaihe. Web 2.0:n ansiosta sisältöjen tuottaminen, jakaminen ja muok-

1. Perinteisemmin voidaan puhua myös tietokonevälitteisestä viestinnästä (engl. computer-mediated communication), mutta Helasvuon, Johanssonin ja Tanskasen (2014: 11) tapaan käytän termiä digitaalinen, joka ei rajaa pois mitään verkon kielenkäytön muotoa (vrt. Herring, Stein \& Virtanen 2013: 5). 
kaaminen internetissä onnistuu teoriassa keneltä tahansa verkon käyttäjältä, ei vain yksittäisiltä, teknologiaan perehtyneiltä henkilöiltä. Nykyisin Web 2.0:aa kutsutaan usein myös sosiaaliseksi mediaksi, mikä kuvaa sille olennaista verkottumista ja yhteistyötä merkitysten ja sisältöjen luomisessa. (Luzón 2009: 76; Pönkä 2014: 11; Helasvuo, Johansson \& Tanskanen 2014: 10-11; Eisenlauer 2013: 6; Web 2.0:n historiasta ks. esim. Herring, Stein \& Virtanen 2013: 12-15.) Käytän ilmausta blogi viittaamaan blogin kaikkien tekstien muodostamaan kokonaisuuteen ja ilmausta (blogi)teksti viittaamaan yksittäiseen kirjoitukseen (engl. blog entry tai blog post). Tässä luvussa tarkastelen ensin lyhyesti blogien tyypillisiä piirteitä (1.1) ja sen jälkeen tarkemmin yhtä piirrettä, hyperlinkkiä (1.2), sekä hyperlinkkejä koskevaa tutkimusta (1.3).

\subsection{Blogit digitaalisen viestinnän välineenä}

Blogia voi ajatella viestintä- tai palvelualustana, joka sisältää useita genrejä ja jolla on tietynlaisia teknologisia affordansseja eli käyttömahdollisuuksia (esim. Grafton 2009: 86; Miller \& Shepherd 2009: 283; Eisenlauer 2013: 48-49; suomenkielinen termi ks. Virtanen, Rahtu \& Shore tulossa 2018). Toisaalta sen voi nähdä ylägenrenä, jolla voi olla lukuisia alagenrejä (esim. Giltrow \& Stein 2009: 9-10; Heyd 2009: 245-247; Rydenfelt 2016: 211). Tässä artikkelissa määrittelen tarkastelemani terveys- ja ravitsemusaiheiset, yksityishenkilöiden ylläpitämät yleistajuiset tiedeblogit alagenreksi, joka tuottaa ainakin osittain samanlaista, yleistajuista tiedonkerronnan diskurssia (ks. Puschmann 2009: 54). Blogeille ei kuitenkaan ole yhtenäisiä, sitovia käytäntöjä, ja sosiaalisen median nopeatempoisessa maailmassa käytännöt elävät jatkuvasti (ks. Rydenfelt 2016: 209-210, 220). Siten yksittäisten blogien tai blogitekstienkin välillä voi olla huomattavia eroja esimerkiksi tavoitteiden suhteen (Puschmann 2009: 52-54; 2013: 84).

Blogin genremääritelmät ovat muuttuneet ajan mittaan (esim. Miller 2014: 62, 64), mutta on hyödyllistä tunnistaa muutamat useille blogeille tyypilliset piirteet ja teknologiset käyttömahdollisuudet, kuten kommentointimahdollisuus ja hyperlinkit (Puschmann 2009: 58). Monet blogit perustetaan valmiille blogialustoille tai blogipalveluihin, jotka määrittävät jossain määrin tekniset muotoseikat, kuten blogitekstien käänteisen kronologisen järjestyksen. Niihin kirjoittajalla ei siis yleensä ole mahdollisuutta vaikuttaa, ellei ole ohjelmointitaitoinen. Kirjoittajan rooli ja valinnat tulevatkin esiin muodon sijaan blogin tyylissä ja sisällössä, jotka ovat täysin hänen päätettävissään (Puschmann 2013: 98). Ne luovat kuvaa kirjoittajasta, ja toisaalta tieto kirjoittajasta vaikuttaa hänen blogissaan esittämänsä tiedon vastaanottoon ja evaluointiin (Puschmann 2009: 80-81). Blogi voidaan mieltää kirjoittajansa itseilmaisun ja identiteetin rakentamisen välineeksi, jolla hän pyrkii vakuuttamaan lukijansa (Miller \& Shepherd 2009: 271; Puschmann 2013: 88; Koskinen 2014: 132). Eri alojen asiantuntijoille blogi voikin olla keino mainostaa ja vahvistaa omaa asiantuntijabrändiään.

Sosiaalisen median mittapuulla blogia voi pitää kirjoittajakeskeisenä genrenä (Koskinen 2014: 129-130, 133). Lukijoilla ei esimerkiksi ole mahdollisuutta muokata blogitekstien sisältöä toisin kuin vaikkapa Wikipedian artikkeleita. Blogi toki usein mahdollistaa kirjoittajan ja lukijan välisen keskustelun kommenttien kautta (ks. Virtanen \& 
Juvonen tulossa 2018), mutta esimerkiksi tiedeblogeissa keskustelu voi todellisuudessa jäädä vain asiantuntijoiden väliseksi (Kouper 2010: 10).

\subsection{Hyperlinkit digitaalisen viestinnän piirteenä}

Yksi varhaisimmista blogien (ns. weblogien) muodoista oli kerätä hyperlinkkilistoja kiinnostaville verkkosivuille (Mauranen 2013: 10). Hyperlinkkejä ja niillä toisiin verkon teksteihin viittaamista pidetään edelleenkin blogille tyypillisenä piirteenä (esim. Puschmann 2009: 54, 57-58).

Hyperlinkki on algoritmipohjainen viittaus yhdestä digitaalisesta tekstistä tai tekstinkohdasta toiseen. Tässä artikkelissa käytän termiä ankkuriteksti² viittaamaan niihin merkkeihin, joihin hyperlinkki on upotettu. Kohdetekstillä puolestaan tarkoitan sitä tekstiä, kuvaa, videota tai muuta digitaalista sisältöä, johon hyperlinkin avaaminen kulloinkin johtaa.

Blogitekstiä voi tarkastella myös hypertekstinä: erilaisista alasivuista ja välilehdistä koostuvana ja toisille sivustoille ja toisiin teksteihin hyperlinkeillä viittaavana kokonaisuutena (Puschmann 2013: 84; ks. myös esim. Landow 1994: 1; Tyrkkö 2011: 21-24). Internetin sisällöstä suurin osa on tällaisia hypertekstejä, ${ }^{3}$ ja hyperlinkkien käyttö on tavanomaista blogien ohella monenlaisessa digitaalisessa viestinnässä, esimerkiksi sähköpostiviesteissä, verkkolehdissä ja verkkokaupoissa. Verkossa olevan hypertekstin ja sen kohdetekstien muodostama kokonaisuus on alati elävä, sillä kohdetekstit voivat poistua tai muuttua, mikä vaikuttaa myös hypertekstistä tehtäviin tulkintoihin.

\subsection{Aiempaa tutkimusta hyperlinkeistä}

Hyperlinkkejä ja digitaalisia hypertekstejä on tutkittu digitaalisen viestinnän alkuvaiheista lähtien (esim. Bernstein 1988; Landow 1989, 1994; Aarseth 1994). Kun tietokonepohjainen viestintä oli vielä harvojen käsissä, tutkittiin muun muassa, miten kirjoittaja voisi muotoilla hyperlinkit helpottaakseen lukijan työtä ja navigointia hypertekstissä (Bernstein 1988; Landow 1989). Sittemmin hypertekstien yleisyys ja ominaisuudet ovat muuttuneet ajasta ennen internetiä ja etenkin Web 2.0:aa (esim. Eisenlauer 2013: 56). Nyt digitaalisten hypertekstien tuottaminen ja muokkaaminen verkossa on monelle arkipäivää, ja ymmärrettävästi myös hyperlinkkejä koskeva tutkimus on muuttunut normatiivisesta deskriptiivisempään suuntaan. Hyperlinkkejä on tutkittu muun muassa vuorovaikutuksen kannalta verkkokaupoissa (Laine 2004) ja yritysten verkkosivuilla (Öhman 2018) sekä linkkien muodostamien verkostojen näkökulmasta blogeissa (Herring, Kouper, Paolillo, Scheidt, Tyworth, Welsch, Wright \& Yu 2005), akateemisissa artikkeleissa (Kim, Park \& Thelwall 2006) ja poliittisten puolueiden verkkoviestinnässä (Hsu \& Park 2010). Yleistajuisen tiedonkerronnan näkökulmasta on tarkasteltu sitä, miten erilaiset

2. Ankkuriteksti on suomennokseni Luzónin $(2009,2013)$ käyttämästä termistä anchor text. Muita ankkuritekstistä käytettyjä termejä ovat muun muassa link element (Tyrkkö 2011) ja i-text (Laine 2004).

3. Kaikki internetissä olevat tai muut digitaalisessa muodossa olevat tekstit eivät kuitenkaan ole hypertekstejä: esimerkiksi sähkökirja ei välttämättä sisällä yhtäkään hyperlinkkiä. 
teksti- ja hyperlinkkirakenteet vaikuttavat tekstin luettavuuteen ja oppimiseen (Yaros 2011). Hyperlinkkien käyttöä on tutkittu myös muun muassa englanninkielisissä akateemisissa tiedeblogeissa (Luzón 2009, 2013) sekä hypertekstikaunokirjallisuudessa (esim. Eskelinen 2002; Tyrkkö 2011).

\section{Teoreettis-metodologiset lähtökohdat ja aineiston esittely}

Seuraavaksi esittelen niitä käsitteitä ja teoreettisia lähtökohtia, joihin hyperlinkkejä koskeva analyysini tukeutuu (2.1). Alaluvussa 2.2 esittelen aineistoni ja sen analysointitavan.

\subsection{Dialogisuus kielellisen toiminnan tausta-ajatuksena}

Analyysissa teoreettisena ja metodologisena tausta-ajatuksenani on käsitys kielen luontaisesta dialogisuudesta. Dialogisuutta on yhtäältä kielellisen ilmaisun suhde muihin samasta aiheesta esitettyihin ilmaisuihin: se on aina reaktio johonkin ennalta sanottuun ja samalla tulevien vastausten ennakointia. Kielellä voidaan siten luoda intertekstuaalisia suhteita edeltäviin ja tuleviin ääniin ja teksteihin. (Esim. Bahtin 1986 [1953]: 69, 91-10o; Vološinov 1990 [1929]: 92; Kristeva 1993 [1967]: 22-23; Linell 1998: 161-166; Makkonen-Craig 2005: 25-26.) Myös hyperlinkeillä voidaan luoda suhteita toisiin teksteihin. Tosin siinä missä niin sanotun perinteisen tekstin intertekstuaalinen suhde toiseen tekstiin luodaan leksikaalisin ja syntaktisin keinoin, sähköisessä hypertekstissä viittaussuhde perustuu hyperlinkin algoritmipohjaisuuteen. Viittaus on huomattavissa pelkistetyimmillään kielenulkoisesta, visuaalisesta vihjeestä: esimerkiksi tietokoneen kursori muuttuu hyperlinkin päällä osoittimeksi.

Toisaalta dialogisuutta on myös kielen toiseensuuntautuneisuus eli ilmaisulla luotava suhde lukijaan: kielenkäyttö suunnataan aina jollekin (kuvitellulle) vastaanottajalle (Bahtin 1986 [1953]: 94-98; Martin \& White 2005: 92, 135; Linell 2009: 99-110; Juvonen 2014: 73; Virtanen 2015: 26). Ajateltu lukija ohjaa kielenkäytön valintoja ja arvotuksia: mitä kerrotaan ja mitä jätetään kertomatta, miten tieto kehystetään ja miten sen paikkansapitävyydestä neuvotellaan (esim. Hyland 2010: 117; Mauranen 2013: 14)? Lukijalla ei tarkoiteta vain aktuaalista vuorovaikutuksen osapuolta vaan yhtä lailla tekstiin kirjoittuvaa lukijaa (Martin \& White 2005: 95; Linell 2009: 69, 99-110; Nord 2015: 123; ks. myös Jaakola, Töyry, Helle \& Onikki-Rantajääskö 2014: 641), josta käytän termiä lukijapositio (reader-in-the-text, ks. Thompson \& Thetela 1995). Blogitekstin hyperlinkkiviittaukset kohdeteksteineen ja muotoineen ovat osa niitä valintoja, jotka luovat näitä positioita. Yhtä lailla nämä valinnat ohjaavat tulkintaa kirjoittajasta: minkälaiseen kirjoittajapositioon (writer-in-the-text, ks. mp.) tämä niiden valossa ja lukijaposition vastinparina asettuu?

Diskurssintutkimuksessa oleellista kielellisten ilmaisujen - tässä tapauksessa hyperlinkkien - tarkastelussa on ottaa huomioon niiden laajempi toimintakokonaisuus (ks. Makkonen-Craig 2005: 28; Pietikäinen \& Mäntynen 2009: 13-14, 29-37; Linell 2009: 383; Virtanen 2015: 38-39). Mikrotason kielenkäyttöä analysoidessani huomioin siksi 
hyperlinkin paikallisen, sekventiaalisen kontekstin: mitä tekstissä tehdään sen edellä ja jäljessä ja miten linkki liittyy tähän kielelliseen toimintaan eli minkälaiseen sekvenssiin se asettuu (ks. Linell 1998: 85-86; Makkonen-Craig 2005: 27; Virtanen 2015: 17, 34)? Kielellinen toiminta voi muodostaa enemmän tai vähemmän vakiintuneita toimintokuvioita ${ }^{4}$, kuten kysymys-vastaus, väite-perustelu ja ongelma-ratkaisu, joiden vakiintuneisuus riippuu muun muassa tekstin genretulkinnasta (Virtanen mts. 39-41).

Blogiteksteissä olevien hyperlinkkien lukemiseen ja tulkintaan voivat vaikuttaa myös monenlaiset blogikohtaiset kynnystekstit (myös: parateksti, ks. Genette 1993: 1-2; Hiidenmaa tulossa 2018), kuten otsikot, kirjoittajan esittelyteksti ja muut metatekstuaaliset lukuohjeet, jotka huomioin hyperlinkkien analyysissa. Tulkintaan vaikuttavaan tilanteiseen kontekstiin liittyvät toisaalta myös kielenkäytön fyysinen ympäristö sekä sen suomat resurssit ja asettamat rajoitteet (Pietikäinen \& Mäntynen 2009: 32) blogitekstien tapauksessa esimerkiksi niiden digitaalinen ja hypertekstuaalinen luonne. Koska kieli on läpeensä sosiaalinen ja vuorovaikutuksessa syntyvä (joint construction, ks. Linell 1998: 86-87), tärkeä mikrotason kielellisen toiminnan tulkintaa ohjaava tekijä on myös se kulttuurinen, historiallinen ja yhteiskunnallinen toimintaympäristö, jossa kielenkäyttö tapahtuu, sekä tuon yhteisön jakamat arvot ja normit (Pietikäinen \& Mäntynen 2009: 35-36; Virtanen 2015: 34). Tämän artikkelin puitteissa huomioinkin muun muassa kirjoittajien akateemisen taustan tuomat odotukset.

\subsection{Aineisto ja sen analyysitapa}

Tutkimukseni ydinaineisto koostuu suomalaisen ravitsemusasiantuntijan, elintarviketieteiden maisteri Patrik Borgin kirjoittamista blogiteksteistä. Borg muun muassa tarjoaa ravitsemusneuvontaa yksityishenkilöille ja yrityksille, luennoi alan asiantuntijoille ja on mukana tekemässä ravitsemustutkimusta. Hän on myös kirjoittanut ja julkaissut useita painonhallintaa käsitteleviä yleistajuisia teoksia ja esiintynyt useasti asiantuntijahaastateltavana eri medioissa. Borg on pitänyt maaliskuusta 2011 lähtien Pöperöproffanimistä blogia ${ }^{5}$.

Maaliskuuhun 2018 mennessä PP-blogissa oli julkaistu yhteensä 133 tekstiä (uusin tammikuussa 2018), jotka olen lukenut läpi kokonaiskuvan saamiseksi. Lokakuussa 2016 poimin kaikista blogin silloisista teksteistä 30 tekstiä tarkempaan analyysiin siten, että mukana on niin blogin alkuvaiheen tekstejä kuin sellaisia, jotka olivat tuolloin uusia julkaisuja, tekemättä kuitenkaan sen tarkempaa ennakkokarsintaa. Lista blogiteksteistä ja niiden julkaisupäivämääristä on artikkelini liitteenä. Olen laskenut näiden 30 tekstin hyperlinkkien lukumäärät ja luokitellut ne kohdetekstien perusteella sekä tarkastellut, minkälaisiin sekvensseihin ja toimintokuvioihin hyperlinkit teksteissä sijoittuvat.

Ydinaineistosta tekemiäni havaintoja tuen vertailuaineistolla, johon kuuluu kolme blogia: Lihastohtori, Pronutritionist ja Ruokamysteerit. Vertailuaineistoa en ole käynyt systemaattisesti läpi, vaan poimin maaliskuussa 2017 näistä blogeista esimerkkejä,

4. Toimintokuvio on mm. Virtasen (2015) käyttämä termi. Makkonen-Craig (2005) puolestaan käyttää vakiintuneista kielellisen toiminnan yhteenliittymistä termiä toimintasarja.

5. Tästä eteenpäin PP-blogi. 
jotka yhtäältä tukevat ydinaineistosta tekemiäni havaintoja ja toisaalta osoittavat eri blogien välisten käytäntöjen eroja (ks. lista esimerkkeinä käytetyistä teksteistä artikkelin liitteestä). Myös vertailuaineiston blogiteksteissä käsitellään tutkimukseen pohjautuen mutta yleistajuisesti terveyttä ja ravitsemusta, ja ne ovat kaikki yksittäisten asiantuntijoiden kirjoittamia. Koska tavoitteeni on tarkastella nimenomaan tieteelliseen tietoon perustuvia blogitekstejä, oleellista sekä ydin- että vertailuaineiston valinnassa on kirjoittajien akateeminen tausta ja siten se, että heillä on kokemusta tutkitun tiedon seulomisesta ja analysoimisesta. Yleistajuisen tiedeblogin määritelmä ei ole yksiselitteinen (ks. Mahrt \& Pushcmann 2014: 2). Tässä artikkelissa määritelmän perusteena on, että kirjoittajalla on akateeminen tutkinto ja mahdollisesti tutkimuskokemusta blogin aihepiirin tieteenalalta, mutta hänen ei tarvitse työskennellä tutkijana.

Kirjoittajille on taustansa ansiosta oletettavasti tuttua paitsi tieteellinen argumentointi ja viittauskäytäntö myös yleistajuinen kirjoittaminen, sillä he kaikki ovat kirjoittaneet blogiensa aiheista myös yhden tai useamman populaarin tietokirjan. Tarkastelemani blogitekstit rakentavat kirjoittajiensa asiantuntijabrändiä, ja kirjoittajat jakavat niissä tutkimukseen perustuvan tiedon ohella näkemyksiään ja mielipiteitään, jotka ovat karttuneet heidän omasta työkokemuksestaan ja harrastuneisuudestaan. Blogit ovat itsenäisiä, eivät siis esimerkiksi työnantajan blogeja; osa kirjoittajista ilmoittaa eksplisiittisesti blogin olevan erillään heidän päivätyöstään. Siten niiden kirjoittajilla on valta kirjoittaa, mistä haluavat. (Ks. Puschmann 2009: 54; Rydenfelt 2016: 211.) Blogi voi silti olla kirjoittajille yksi kanava hankkia asiakkaita omien asiantuntijapalveluidensa pariin, mitä tulkintaa tukee esimerkiksi PP-blogin kirjoittajan esittelyteksti, jossa mukana ovat myös hänen vastaanottojensa yhteystiedot: ${ }^{6}$

Olen ravitsemusasiantuntija, joka seikkailee vastaanottotyön, kirjailijuuden/ kirjoittamisen, luennoinnin, tutkimuksen, tyhy-toiminnan ja erilaisten asiantuntijatehtävien välimaastossa. Nyt mm. Suomen Lihavuustutkijat ry:n puheenjohtaja. Blogin toivon auttavan ihmisiä toteuttamaan syömistä ja muitakin elintapoja paremmin, helpommin, mielekkäämmin ja ilman ylimääräisiä kikkailuja tai hankaluuksia. Vastaanotot Helsingin Urheilulääkäriasema, Dextra Kamppi ja Syömishäiriökeskus - joskus ei vain itse pääse eteenpäin vaikka lukisi kaikki kirjani ja tekstini. Yhteydenotot etävastaanottojen ja luentojen osalta patrik.borg(a)hula.fi.

Esittelyteksti toimii kynnystekstinä ja ohjeena, miten blogia tulisi lukea ja hyödyntää: yhtäältä blogi on tarkoitettu avuksi kenelle tahansa terveistä elintavoista kiinnostuneelle, toisaalta se tarjoaa potentiaalisille asiakkaille väylän kirjoittajan vastaanotolle.

\section{Hyperlinkkien kohteet ja funktiot}

Tässä luvussa tarkastelen hyperlinkkien funktioita aineistosta tekemieni havaintojen perusteella (alaluvut 3.2-3.5). Esimerkit ja havainnot perustuvat PP-blogiaineistoon,

6. Kaikki aineistosta poimitut sitaatit ja esimerkit ovat alkuperäisessä kirjoitusasussaan. 
ellen toisin mainitse. Yleiskuvan luomiseksi esittelen ensin (3.1), kuinka paljon hyperlinkkejä PP-blogiaineistossa on ja minkälaisiin kohdeteksteihin ne viittaavat.

\subsection{Hyperlinkkien määrä ja kohteet ydinaineistossa}

Analysoimissani 30:ssä PP-blogin tekstissä on yhteensä 207 hyperlinkkiä.7 Suurimmaksi viittauskohteeksi hahmottuvat pääasiassa ulkomaiset ja englanninkieliset (luonnon-) tieteelliset artikkelit ja artikkelitietokannat (esim. NCBI: $n^{8}$ PubMed-tietokanta ja sen artikkelit). Niihin johtaa 109 linkkiä eli yli puolet kaikista linkeistä. Seuraavaksi eniten, 38 kertaa, kirjoittaja viittaa hyperlinkillä omaan tekstiinsä, joko PP-blogissa aiemmin tai myöhemmin julkaistuun tekstiin tai jollain muulla foorumilla julkaistuun kirjoitukseen. Erilaisille terveyteen liittyvien instituutioiden sivustoille (esim. UKK-instituutin verkkosivuille) johtaa 20 hyperlinkkiä, toiseen yleistajuiseen blogiin 8 linkkiä ja sanoma- tai aikakauslehden (esim. Kalevan) verkkosivulle tai muun perinteisen mediatoimijan (esim. Ylen) verkkosisältöön 7 linkkiä. Linkeistä 8 johtaa Wikipedia-artikkeliin. Muille yleistajuisille sivustoille kuin omaan tekstiinsä kirjoittaja viittaa hyperlinkillä siis yhteensä 43 kertaa. Linkeistä 9 ei johda mihinkään: niiden URL-osoitteet ovat joko vanhentuneita tai muuten virheellisiä, ja niitä klikatessaan lukija saa vain virheilmoituksen.

\subsection{Viittaaminen hyperlinkin perusfunktiona}

Kaikenlaisten hyperlinkkien yhteisenä perusfunktiona voi pitää viittaamista toiseen tekstiin ja lukijan ohjaamista tuon tekstin ääreen. Linkki siis paitsi viittaa toiseen tekstiin myös tarjoaa mahdollisuuden päästä välittömästi tekstiin "käsiksi". Viittaamisen ohella linkeille hahmottuu aineistosta muitakin funktioita, joita tarkastelen alaluvuissa 3.3-3.5: linkeillä selitetään tekstissä esiintyviä käsitteitä ja ilmaisuja, tarjotaan tieteellinen lähdeviite ja tuetaan kirjoittajan argumentaatiota sekä kontekstualisoidaan tekstin puheenaihetta (ks. myös Luzón 2009: 86; 2013: 443-444). Tässä hyperlinkit toimivat monifunktioisesti kuten kieli ylipäätään: pienimmälläkin kielellisellä ilmaisulla välitetään yhtä aikaa monia merkityksiä (esim. Shore 2012: 142), niin myös hyperlinkeillä.

Tekstissä hyperlinkkien eri funktiot etualaistuvat riippuen siitä, minkälaiseksi niitä ympäröivän kielellisen toiminnan voi tulkita. Viittausfunktio etualaistuu etenkin silloin, kun lukijan ohjaaminen kohdetekstiin tehdään metatekstin avulla eksplisiittisesti ja hyperlinkki upotetaan vaikkapa deiktiseen viittaukseen kuten esimerkeissä 1 ja 2:

(1) Olen tekemässä parhaillaan kirjaa laihdutuksen moninaisista vähemmän selostetuista asioista ja tulin aineenvaihdunnallisiin asioihin. Kirjoitin vuonna 2003 artikkelin säästöliekistä keho.nettiin ja juttu löytyy täältä. Koska hie-

7. Rajaan tarkasteluni päivättyihin blogiteksteihin ja niissä oleviin hyperlinkkeihin. Niiden lisäksi esim. blogin sivupalkissa (sidebar) voi olla linkkejä toisiin blogeihin (ns. blogroll) tai aihetunnistelinkkejä.

8. NCBI, National Center for Biotechnology Information, on osa Yhdysvaltojen kansallista terveyskirjastoa (National Library of Medicine, NLM). 
man päivitin säästöliekkiasiaa kirjaani varten, niin ajattelin heittää sen myös tänne. $(7)^{9}$

(2) Tässähän ei ole mitään ihmeellistä vaan kaikillehan on tuttua, että pelot ja huolet aniharvoin ovat mitään kovin rationaalisia: lentopelon sijasta autopelko olisi järkevämpää jne... Tässä muuten kiva blogi aiheesta, (13)

Molemmissa esimerkeissä kohdetekstiin viittaaminen nostetaan siis kielelliseksi toiminnoksi, vaikka hyperlinkin ansiosta viittauksen voisi upottaa tekstin propositionaaliseen sisältöön. Esimerkit 1 ja 2 eroavat toisistaan linkin ankkuritekstin pituuden sekä kohdetekstistä annettavien tietojen ja sen relevanssin esittelyn suhteen: Esimerkissä 1 leipätekstissä kerrotaan kohdetekstin kirjoittaja, julkaisuvuosi ja -paikka, esimerkissä 2 vastaavia tietoja ei anneta ja ne käyvät ilmi vasta linkkiä seuraamalla. Esimerkissä 1 kohdetekstin linkittämisen ajankohtaisuus ja relevanttius perustellaan linkin kontekstissa, kun taas esimerkissä 2 partikkeli muuten ohjaa tulkintaan, että kohdeteksti mainitaan vain sivuhuomiona (ks. VISK $2004 \$ 810$ ) eikä se ole oleellinen käsillä olevan tekstin kannalta.

Viittaamisfunktion korostuminen ei vaadi deiktisten viittausten käyttämistä, mistä esimerkkinä on seuraava Ruokamysteerit-blogista poimittu esimerkki:

(3) Aiheeseen liittyvä artikkeli:

https://www.eatingdisorderhope.com/information/anorexia/vegan-vegetarianrelationship-rates $(\mathrm{RM})$

Tässä linkkiä edeltää kohdetekstiä luonnehtiva metateksti ja linkki puolestaan on upotettu kohdesivun URL-osoitteeseen. Osoitteen aukikirjoittamista voi pitää digitaalisessa blogitekstissä huomiota herättävänä ja käytännössä tarpeettomana, sillä linkki ohjaa suoraan kohdetekstiin - lukijan ei tarvitse siis muistaa tai kopioida osoitetta. URL-osoite antaa kuitenkin jonkin verran lisätietoa kohdetekstistä, kuten että sivu on englanninkielinen.

\subsection{Hyperlinkki selventävän lisätiedon antajana}

Hyperlinkin avulla kirjoittaja voi tarjota lukijalle johonkin blogitekstissä esiintyvään ilmiöön liittyvää lisätietoa; selventävänä ja syventävänä kohdetekstinä voi olla esimerkiksi tieteellinen tai Wikipedia-artikkeli, lehtijuttu tai kirjoittajan oma aiempi blogiteksti. Edellä esimerkeissä 1-3 tämä lisälukemisen tarjoaminen tehdään eksplisiittisesti, metatekstin avulla lukijaa ohjaten. Sen sijaan esimerkissä 4 kohdeteksteihin ei viitata kielellisesti lainkaan eikä viittauksiin yhdisty myöskään mainintaa lisätiedon tarjoamisesta:

9. Esimerkeissä kursivoidut kohdat merkitsevät linkin paikkaa eli ankkuritekstiä. Numerointi esimerkin perässä kertoo, mistä aineiston blogitekstistä esimerkki on (ks. liite). Pidempiin esimerkkeihin on lisätty rivinumerot helpottamaan analyysin seuraamista. 
(4) Hyvä syöminen - laihdutustavoitteella tai ilman - ei vaadi yhdenkään ruokaaineen kalorien tuntemista saati niiden laskemista yhteen. Se, että alkaa syömään uudella rytmillä, uudenlaisia ruokia ja uudella ajatuksella ei liity kaloritietoon mitenkään. (6)

Esimerkki 4 on blogitekstistä, jossa kirjoittaja käsittelee kalorien laskemisen etuja ja haittoja painonhallinnassa. Tekstissä ja esimerkin 4 katkelmassa hän esittää kalorien laskemisen hyödyttömäksi ja perustelee sitä hyperlinkit sisältävällä virkkeellä. Ilmaukset uudella rytmillä ja uudella ajatuksella (syöminen) ovat epätarkkoja ja monitulkintaisia, mutta ankkuriteksteinä ne toimivat eräänlaisina kohdetekstien otsikkomaisina kynnysteksteinä ja lukuohjeina (ks. Tyrkkö 2011: 163, 165; Luzón 2013: 446): kohdetekstit siis käsittelevät jollain tavalla näitä aiheita. Esimerkin 4 linkit johtavatkin kirjoittajan aiempiin blogiteksteihin, ensimmäinen otsikolla "Tasainen ateriarytmi", toinen otsikolla "Syömishuolista eroon". Niiden avulla hän voi syventää ilmausten merkitystä lipsumatta kuitenkaan sivuun käsillä olevan blogitekstin puheenaiheesta.

Luzónin tarkastelemissa yleistajuisissa tiedeblogeissa linkeillä voidaan tarjota yleistajuinen selitys tieteelliselle käsitteelle esimerkiksi viittaamalla Wikipedia-artikkeliin (Luzón 2009: 84; 2013: 443-444). Myös PP-blogissa on vastaavia esimerkkejä:

(5) 01 Myytti nro 4: Henkilön "valmiustila" painonlaskuun ennustaa O2 parempaa painonhallintaa

O3 Tutkijoiden toteamus nro 4: Ei ennusta

04 Pöperöproffan näkemys: Ei ennusta, mutta en nyt tiedä onko tämä

05 myytti

o6 Tässä taustalla on pitkälti terveyskäyttäytymisen puolella

07 paljon käytetty "Stages of change" -malli, jonka tarkoitus on arvioida

o8 henkilön valmiutta elintapamuutokseen. Malli sisältää myös paljon

o9 muitakin muutosprosesseineen ja sen sellaisineen. (21)

Esimerkki 5 on blogitekstistä, jossa kirjoittaja arvioi laihdutukseen liittyviä uskomuksia käsittelevää tieteellistä artikkelia. Esimerkin riveillä 1-2 on artikkelissa esitetty myytti, rivillä 3 artikkelin kirjoittajien näkemys siitä, riveillä 4-5 PP-blogin kirjoittajan näkemys ja sen jälkeen hänen perustelunsa näkemykselleen. Ensimmäinen linkki kirjoittajan perusteluissa johtaa englanninkieliseen Wikipedia-artikkeliin "Transtheoretical model", joka on toinen nimitys Stages of change -mallille. Kirjoittaja esittelee leipätekstissä tämän mallin tarkoitusta yleisluonteisesti (ilmaisulla arvioida valmiutta elintapamuutokseen, johon on upotettu linkki Terveyskirjaston sivulle ${ }^{10}$ ), mutta Wikipedia-artikkeli tarjoaa yksityiskohtaisemman selostuksen mallista.

Toisaalta tieteelliseen termiin tai lyhenteeseen upotettu linkki voi ohjata PP-blogissa myös tieteelliseen artikkeliin kuten esimerkissä 6:

10. Linkin avaaminen tosin tuottaa virheilmoituksen "pyytämääsi sivua ei löytynyt". 
(6) 01 Halusi tai ei, niin tietty osa fyysisestä aktiivisuudesta pienenee laihdutuk02 sen aikana. - - Tämä tiedostamaton liikunta koostuu erilaisesta näperteo3 lystä, jalkojen heiluttamisesta, sormien pyörittelystä, kehon painopisteen 04 vaihtelusta ja muusta liikkeistä, joita emme edes ajattele, mutta silti 05 teemme. Tieteessä tälle aktiivisuudelle on annettu nimi non-exercise aco6 tivity thermogenesis (NEAT), mutta hypistely, levottomuus, puuhailu voisivat kaikki olla osuvia kuvauksia aktiviteetille. (7)

Esimerkissä 6 hyperlinkkiä edeltävässä sekvenssissä kirjoittaja kuvaa yleistajuisesti tiettyä fyysisen aktiivisuuden muotoa, minkä jälkeen hän nimeää tämän ilmiön tieteellisellä termillä ja termin lyhenteellä (r. 5-6). Kun ilmiö on esitetty yleistajuisesti jo leipätekstissä, linkki kohdeteksteineen tuntuu olevan osoitettu ennemmin toiselle asiantuntijalle (vrt. Luzón 2013: 444). Linkki voi myös toimia lähdeviitteenä, joka tuo ilmiön esittelylle tieteellistä vakuuttavuutta. Tätä funktiota käsittelen lisää seuraavassa alaluvussa.

\subsection{Hyperlinkki tieteellisenä lähdeviitteenä}

Hyperlinkit tieteellisiin teksteihin toimivat eräänlaisina lähdeviitteinä ja antavat kirjoittajan argumentaatiolle tieteellistä vakuuttavuutta (ks. myös Luzón 2009: 82-83; 2013: 445). PP-blogin tutkimusviitteiden tulkintaa ohjaa kuitenkin huomautus, joka on kirjoitettu blogin alatunnisteeseen (footer):

En käytä tutkimusviitteitä blogissani kaikenkattavina selityksinä kirjoituksiin. Jos niin tekisin, niin samantien homma alkaa tuntumaan työltä ja se veisi enemmän aikaa. Juttuni kumpuavat matkan varrella luetuista tutkimuksista ja ne edustavat luomaani synteesiä tutkimuskokonaisuudesta ja käytännön näkökulmista. Viitteissä en kuitenkaan esittele tutkimuskokonaisuutta vaan esimerkinomaisesti viittaan johonkin havaintoon niitä varten joita viitteet kiinnostavat. Eli yleensä kirjoitan blogautuksen ja sitten kaivan esiin viitteet jos koen tarpeelliseksi. Epätieteellistä - tavallaan. Nopeaa ja mielekästä - kyllä.

Tämä lukuohje koskee ainoastaan tutkimuksiin ohjaavia linkkejä: kirjoittaja korostaa, että ne ovat vain esimerkinomaisia havaintoja eivätkä hänen argumenttinsa perustu pelkästään niihin. Sen sijaan kirjoittaja nostaa kirjoitustensa "selityksiksi" oman kokemuksensa ja kartuttamansa tieteenalan tuntemuksen.

Tieteellisiin artikkeleihin johtavat hyperlinkit voivat kuitenkin tukea kirjoittajan argumentaatiota, kuten esimerkissä 7 , jossa hyperlinkit on lisätty tutkimustuloksia esittelevien väitteiden perään. Tekstin alussa kirjoittaja on esittänyt omiin asiakastyökokemuksiinsa vedoten, että naisten ja miesten nälänsäätelyssä on eroja ja että painonhallinnassa naisille olisi miehiä tärkeämpää pitää yllä tasaista ateriarytmiä. Sen jälkeen hän tarkastelee aiheeseen liittyvää tutkimusnäyttöä:

(7) 01 Mutta tukeeko tutkimus näitä kokemuksia? Aihepiirin tutkimus on var02 sin vähäistä, se vähäkin on viitteellistä ja varmasti osin siksi ilmiötä ei pi- 
03 detä kovinkaan "totena". Tutkimusnäytöstä voi sanoa, että

04 - erilaiset mieliteot ovat naisilla hyvin selvästi miehiä yleisempiä $(1,2,3,4)$

05 - naisten kylläisyyden kestosta ja ateriarytmien tarpeen erilaisuudesta

o6 ei löydy juurikaan tutkimusta, joka vastaisi juuri tämän blogautuksen

07 kysymykseen. Vain viitteellisesti nähdään satunnaisesti, että naiset tun-

o8 tuvat hyötyvän miehiä enemmän erilaisista verensokeria tasaavista teki-

o9 jöistä (mm. glykeeminen kuorma 1, HH vs. Proteiini 2). Vain tutkimusta

10 katsottaessa ilmiötä voi siis epäillä nälänhallinnan osalta ja joskus tör-

11 määnkin siihen, että asiaa pidetään urbaanina legendana. Tutkimus-

12 näytön pohjalta sitäkin mieltä voi olla, mutta tutkimusta on aika vähän

13 tästä aiheesta ja olen toistaiseksi eri mieltä. (16)

Hyperlinkit on upotettu numeroihin väitteiden perään. Linkkien kohdetekstit asettuvat esimerkeiksi tutkimuksista, jotka tukevat kirjoittajan argumenttia, että naisille tasainen ateriarytmi on tärkeämpää kuin miehille. Kaikki linkit johtavat englanninkielisiin tieteellisiin artikkeleihin, joista jokainen käsittelee jollain tavalla naisten ja miesten nälänsäätelyn eroja. Kappaleen aloittavaa kysymystä (Mutta tukeeko tutkimus näitä kokemuksia? r. 1) seuraa vastaussekvenssi: ensin tutkimusnäytön riittävyyttä ja luotettavuutta evaluoiva sekvenssi (Aihepiirin tutkimus on varsin vähäistä, se vähäkin on viitteellistä ja varmasti osin siksi ilmiötä ei pidetä kovinkaan "totena", r. 1-3) ja sen jälkeen tutkimusnäyttöä erittelevä sekvenssi, johon myös hyperlinkkiviittaukset sijoittuvat (r. 3-9). Rivin 4 hyperlinkkien voi tulkita liittyvän väitteeseen erilaiset mieliteot ovat naisilla hyvin selvästi miehiä yleisempiä ja tukevan sitä, koska siihen ei liity kontrastiivisuutta ilmaisevia elementtejä (ks. VISK $2004 \$ 1101$ ). Vastaavasti rivin 9 hyperlinkit asettuvat tukemaan väitettä, jonka mukaan naiset tuntuvat hyötyvän miehiä enemmän erilaisista verensokeria tasaavista tekijöistä.

Linkin yhteydessä ei tarvitse eksplisiittisesti mainita tutkimusnäyttöä, jotta linkki tukisi kirjoittajan argumenttia. Tästä esimerkkinä on seuraava katkelma:

(8) Eli jos haluat löytää mielekkään liikunnan niin älä pilaa liikuntaa etukäteen vetämällä liian kovaa. Etsi jollakin tasolla mielekäs liikkumisen tapa ja taso ja karista turhat puristusajattelut pois - se on ihan tarpeeksi tehokasta niinkin. (29)

Esimerkin 8 ankkuritekstissä esitetty väite perustelee edeltävässä sekvenssissä esitettyä kieltoa ja ohjetta. Linkin kohdetekstin - tieteellisen artikkelin - puolestaan voi tulkita ankkuritekstissä esitetyn väitteen tueksi, sillä linkin yhteydessä ei esitetä väitteen kanssa kontrastiivisia ilmaisuja. Olisi siis odotuksenvastaista, jos linkin takaa avautuva teksti esittäisikin vastakkaista (tai täysin irrelevanttia) tietoa kuin ankkuriteksti.

Hyperlinkkiviittaukset tieteellisiin teksteihin toimivat myös retorisena keinona, auktoriteettiin vetoamisena, jossa auktoriteettina on tutkijoiden konsensus (ks. Perelman \& Olbrechts-Tyteca 1971 [1958]: 305-307; Riesch \& Mendel 2014: 62). Kuten tieteellisessäkin viittauskäytännössä, tutkimusviittauksen vakuuttavuus syntyy tiedon tutkittuuden osoittamisesta ja kohdetekstin julkaisukanavasta, vertaisarvioidusta aika- 
kauslehdestä. Tutkimusviittaukset osoittavat, että kirjoittaja seuraa tieteenalansa tutkimusta ja on perillä sen uusimmista tuloksista (ks. myös Luzón 2009: 82), ja niiden avulla hän antaa kunnian tiedon tai ajatuksen alkuperästä sille, jolle se kuuluu.

\subsection{Hyperlinkki tekstin puheenaiheen kontekstualisoijana}

Yhdeksi hyperlinkin funktioksi hahmottuu aineistossa blogitekstin puheenaiheen esittely ja taustoittaminen. Blogeille voidaankin pitää tyypillisenä bloggaamiseen liittyvää metatekstiä, jolla lukijalle esitellään kirjoittamiseen liittyviä motiiveja (Puschmann 2009: 59, 74; ks. myös Mauranen 2013: 20). Aineiston 30 tekstistä 28:ssa on tällaista metatekstiä, kuten maininta siitä, mikä on sysännyt kirjoittajan kirjoittamaan kyseisestä aiheesta: esimerkiksi tutkimustulos, viimeaikainen uutinen tai kirjoitus jossain toisessa blogissa (ks. myös Luzón 2013: 435, 445). Niistä 11 tapauksessa on myös hyperlinkki mainittuun kohdetekstiin kuten esimerkissä 9:

(9) Taas ovat kevyttuotteet olleet otsikoissa ja lööpeissä näkynyt, että olisi löydetty jotakin uutta tietoa ja kevyttuotteista ei olisikaan iloa laihduttajille. Osa minusta olisi ihan tyytyväinen tähän, sillä kevyttuotteet ovat sen verran pikkujuttu hyvässä syömisessä, ettei haittaa vaikka niiden painoarvo ihmisten mielikuvissa pienenisi. Mutta blogautus kuitenkin tuli, sillä vielä enemmän minua harmittaa virheellinen tieto. (26)

Esimerkki 9 on osa blogitekstin ensimmäistä kappaletta, ja linkki johtaa Iltalehden verkkoartikkeliin, jonka otsikko on "Uusin tieto kevyttuotteista: Yllättävä vaikutus painonhallintaan". Esimerkin ja blogitekstin ensimmäinen virke muodostaa taustoitusja esittelysekvenssin, jossa kirjoittaja esittelee kielellisen viittauksen ja hyperlinkin avulla havaitsemansa uutisen. Tämän jälkeen kirjoittaja kertoo, miten hän on reagoinut tähän uutiseen ja mitä mieltä hän siitä on (Osa minusta olisi ihan tyytyväinen tähän - -. Mutta blogautus kuitenkin tuli, sillä vielä enemmän minua harmittaa virheellinen tieto.). Tämä taustoitus puolestaan toimii siirtymänä kirjoittajan oman tekstin aiheeseen, kevyttuotteisiin.

Blogitekstin puheenaihe voi liittyä hyperlinkillä esiteltyyn tekstiin kuten edellisessä esimerkissä tai lähteä uusille urille kuten esimerkissä 10, joka on edellisen esimerkin tavoin blogitekstin aloituskappale:

(10) Kun luin tuossa Reijon mainion VHH-sarjan yhteenvetoa niin siinä oli ruokavaliotyyppien vertailukuva (laihdutustehosta VHH:lla ja vähärasvaisella) joka sai minut miettimään taas kerran tuttua ongelmaa. Mitäs jos omalle käsitykselle hyvästä syömisestä ei ole kategoriaa ja jos on niin ei ainakaan mitään kovin kummoista nimeä? Minä en nimittäin millään keksi miksi muuksi voisin sitä kutsua kuin Hyväksi Ruokavalioksi tai kun syömiskäyttäytymisenkin haluan mukaan niin Hyväksi Syömiseksi. Ei tuo oikein auo ihmisille mistä siinä on kyse. (4) 
Esimerkin 10 ensimmäisestä virkkeestä voi tulkita, että nimenomaan linkitetty kohdeteksti on saanut kirjoittajan pohtimaan omassa blogitekstissään käsittelemäänsä ongelmaa eli nimitystä omalle käsitykselleen hyvästä syömisestä. Esimerkin toimintokuvioksi hahmottuu siten oman tekstin aiheen taustoitus, esittely ja motivointi; olennaista on se, että aihe on juontunut toisesta tekstistä.

Puheenaihetta kontekstualisoivaa hyperlinkkiä voi pitää myös eräänlaisena lähdeviitteenä. Lisäksi kaikki linkit tarjoavat lukijalle yleensä jonkinlaista lisätietoa aiheesta. Hyperlinkkien funktioiden väliset rajat ovat siis häilyviä ja niiden päällekkäisyys ilmeistä.

\section{Hyperlinkit luomassa kirjoittaja- ja lukijapositioita}

Seuraavaksi tarkastelen, minkälainen kirjoittaja ja lukija blogiteksteille rakentuu hyperlinkkien kautta. Ensin (4.1) havainnollistan, miten ankkuritekstin muotoilulla voi ohjata lukijaa. Sen jälkeen (4.2) tarkastelen erilaisten kohdetekstiesimerkkien kautta tekstiin hahmottuvia kirjoittaja- ja lukijapositioita.

\subsection{Ankkuriteksti ohjaamassa lukijaa}

Hyperlinkki voidaan upottaa yhteen tai useampaan sanaan tai vaikkapa kuvaan. Ankkuriteksti ja kielellinen toiminta, johon linkki asettuu, ohjaavat tulkintaa ja arviota kohdetekstistä (ks. Tyrkkö 2011: 163, 165; Luzón 2013: 446). Vaikka viittaus toiseen tekstiin olisikin kielen tasolla implisiittinen, kuten edellä esimerkissä 4 (- Se, että alkaa syömään uudella rytmillä, uudenlaisia ruokia ja uudella ajatuksella ei liity kaloritietoon mitenkään), kertoo ankkuritekstin visuaalinen vihje siitä, että linkin takaa löytyy lisätietoa (ks. Laine 2004: 99-100) ja ankkuriteksti toimii tämän lisätiedon lukuohjeena. Ankkuriteksti voi siten auttaa arvioimaan, onko kohdetekstin lisätieto lukijalle tarpeellista. Toisinaan lukija voi sivuuttaa linkit ja olla avaamatta niitä ilman, että tekstin ymmärrettävyys kärsii. Joskus taas linkin avaaminen voi olla välttämätöntä, mikäli haluaa ymmärtää blogitekstissä esitetyn väitteen, kuten esimerkissä 11:

(11) Laihdutus kannattaa tehdä jotenkin näin - se voi kuulostaa epämääräiseltä, mutta oikeastaan sitä kutsutaan yksilöllisyydeksi, kun on isot linjat joiden sisällä voi tehdä asioita itselle sopivaksi. (18)

Kirjoittajan ohje jää ilman kohdetekstiä vaillinaiseksi: lukija ei voi tietää, mitä jotenkin näin tapahtuva laihdutus tarkoittaa (ks. myös esim. 4). Ankkuritekstin epämääräisyys ja deiktinen viittaus houkuttelevat avaamaan linkin - joka johtaa kirjoittajan aiempaan blogitekstiin - ja sitä kautta täydentämään puuttuvaa tietoa. Näin ollen tekstiin kirjoittuu lukija, joka avaa linkin ja lukee kohdetekstin. Lukijaa ohjataan siten perehtymään aiheeseen syvällisemmin kirjoittajan aiempien tekstien kautta, ei siis lukemaan vain tätä yksittäistä blogitekstiä. Aineistossani tällainen "pakollinen" kohdeteksti on aina yleistajuinen, ei koskaan tieteellinen teksti. 
Vaikka mikään ankkuritekstissä tai sitä ympäröivässä kielellisessä toiminnassa ei antaisi vihjettä kohdetekstin luonteesta, voi vaikkapa tietyn blogin viittauskäytäntö ohjata lukijan tulkintaa kohdetekstistä. Seuraava esimerkki on Lihastohtori-blogista:

(12) Suomestahan transrasvat ovat jo lähes kuolleet sukupuuttoon. (LT)

Esimerkin 12 ankkuriteksti voisi tulla tulkituksi jonkinlaiseksi tutkimustulokseksi ja hyperlinkki tutkimusviitteeksi. Toisaalta tässä blogissa tutkimusviittaukset on pääsääntöisesti upotettu tutkijan nimeen ja julkaisuvuoteen, joten erityisesti blogin vakituinen lukija saattaa jo pelkän ankkuritekstin perusteella päätellä, ettei tässä ole kyse tutkimusviittauksesta: linkki ohjaakin toiseen blogiin.

Kun blogitekstin ja kohdetekstin suhdetta ei selitetä eikä viittaus ole eksplisiittinen, tekstiin kirjoittuu lukija, jota kirjoittajan ei tarvitse ohjata kädestä pitäen: kirjoittaja luottaa lukijan kykyyn huomata ja tulkita hyperlinkit. Voi myös olettaa, että internet-ajan lukija on tottunut digitaalisten tekstien hyperlinkkeihin, ja siksi lukijan opastamista metatekstin avulla ei koeta yhtä tärkeäksi kuin digitaalisen hypertekstuaalisuuden tutkimuksen alkuaikoina (ks. esim. Bernstein 1988; Landow 1989).

\subsection{Lukijana asiantuntija tai maallikko, kirjoittajana asiantuntija}

Asiantuntijoihin ja maallikoihin on perinteisesti vedottu toisistaan poikkeavin strategioin ja argumentein (ks. esim. Hyland 2010). Yleistajuisia tiedeblogeja tutkineen Luzónin (2013: 429, 440) mukaan blogi kuitenkin mahdollistaa molempien yleisöjen puhuttelun samalla kertaa. ${ }^{11}$ Yksi keino siihen ovat hyperlinkit: niiden avulla voidaan samassa tekstissä tarjota lisäluettavaa ja perusteluja taustatiedoiltaan ja perehtyneisyydeltään eritasoisille lukijoille (mas. 436, 443-444). Hyperlinkkien suoma mahdollisuus irrottautua vain yhdenlaisesta lukijasta on ollut oleellinen ajatus niiden tutkimuksessa alusta lähtien (esim. Bernstein 1988: 34).

Lukijapositioita voidaan yhtäältä tarkastella sen kautta, mitä oletetun lukijan otaksutaan tietävän ja miten hän ymmärtää tekstin (esim. Jaakola ym. 2014: 643). Toisaalta lukija- ja kirjoittajapositioita voi tarkastella dialogisen tilan rakentamisen näkökulmasta: millä tavoin kirjoittaja osoittaa tiedostavansa omasta näkökulmastaan poikkeavia näkökulmia, ja kutsuuko hän lukijaa omaksumaan saman kannan vai antaako tilaa olla eri mieltä (Martin \& White 2005: 92-104; Virtanen 2015: 30-33, 45)? Tarkastelen seuraavaksi hyperlinkkien konstruoimia lukija- ja kirjoittajapositioita erilaisten kohdetekstien sekä dialogisen tilan luoman kirjoittaja-lukija-suhteen kautta.

\subsubsection{Kohdetekstinä tieteellinen teksti}

Edellä (ks. alalukua 3.4) siteeraamassani alatunnisteessa kirjoittaja antaa koko blogia koskevan lukuohjeen, jonka mukaan hänen mahdollisia viittauksiaan tieteellisiin läh-

11. Tosin esim. Nord (2015: 130) pitää monenlaisten lukijoiden puhuttelua mahdollisena myös painetuille moderneille multimodaalisille teksteille. 
teisiin tulisi tulkita. Siinä kirjoittaja siis irtisanoutuu bloginsa osalta systemaattisesta tieteellisestä lähdeviittaustekniikasta. Kiellon kautta (En käytä tutkimusviitteitä) hän tulee kuitenkin presupponoineeksi mahdollisen ja jopa odotuksenmukaisen (ks. Martin \& White 2005: 118-120) viittauskäytännön, jossa kuhunkin blogitekstiin liitettäisiin lähdeviitteet (ja blogin tapauksessa erityisesti hyperlinkit). Näillä viitteillä osoitettaisiin, mihin tutkimukseen tai muuhun lähteeseen väitteet perustuvat. Odotuksenmukaisuutta vahvistavat ratkaisua koskevat perustelut, joilla kirjoittaja tuo myös esiin omaa kokemustaan blogin tekstien luotettavuuden takeeksi (esim. Juttuni kumpuavat matkan varrella luetuista tutkimuksista). Viittauskäytännön odotuksenmukaisuus saattaa juontua kirjoittajan akateemisesta taustasta ja hänen tottumuksestaan käyttää tieteellisen viittaamisen konventioita - antaahan hän ymmärtää, että tällainen systemaattinen viittaustapa alkaa tuntumaan työltä. Samalla se luo lukijan, joka odottaa tarkkoja viitteitä tutkimuksiin - esimerkiksi siis toisen alan asiantuntijan tai muuten tieteellisiä lähteitä kaipaavan lukijan - ja perusteluja viitteiden poisjättämiselle (ks. mts. 101-102, 119-120). Toisaalta toteamalla viitteiden olevan niitä varten joita viitteet kiinnostavat kirjoittaja luo myös lukijaposition, jota tutkimusviittaukset eivät kiinnosta. Esittelemällään tutkimusviittauskäytännöllä hän tasapainottelee siis erilaisten lukijoiden odotusten välimaastossa.

Tutkimusviittauksia koskevasta huomautuksesta huolimatta PP-blogiaineistossa on runsaasti hyperlinkkejä tieteellisiin artikkeleihin tai tietokantoihin (109 linkkiä 207 linkistä). Tutkimusviittauksilla voidaankin hakea uskottavuutta sellaisten lukijoiden silmissä, joille tieteellinen tutkimus on auktoriteetti (ks. Mäntynen 2003: 106, 120; Hyland 2010: 122) - esimerkiksi siis toisen ravitsemusasiantuntijan silmissä. ${ }^{12}$ Tutkimusviittaukset tuntuvat kutsuvan asiantuntijalukijoita myös siksi, että mahdollisesti vain toinen asiantuntija tai käsiteltävään aiheeseen muuten hyvin perehtynyt lukija pystyy arvioimaan blogitekstin ja tieteellisen kohdetekstin suhdetta kuten myös sitä, tukeeko kohdeteksti blogitekstissä esitettyjä väitteitä. Tieteelliset kohdetekstit ovat pääasiallisesti englanninkielisiä ja sisältävät ravitsemustieteellistä erikoissanastoa, jolloin maallikon voi olla vaikea arvioida niiden relevanttiutta blogitekstissä esiteltyjen väitteiden kannalta.

Maallikon silmissä tutkimusviittauksien vakuuttavuus voi jäädä sen varaan, että hän luottaa kirjoittajan linkittäneen tekstiin oleellisia kohdetekstejä ja tulkinneen niitä oikein. Jo pelkkä linkin olemassaolo saattaa herättää maallikkolukijassa luottamusta: sen voi tulkita merkiksi kirjoittajan vaivannäöstä ja perehtyneisyydestä aiheeseen (Morkes \& Nielsen 1997). Tieteellisiin teksteihin viittaavien linkkien lukumäärä tuntuu yleistajuiseksi tarkoitetulle blogille (ks. esim. blogin kirjoittajaesittely) suurelta, mikäli niiden tulkitsee olevan osoitettu vain toisille asiantuntijoille. Siksi niiden voi olettaa olevan blogin kirjoittajan tapa rakentaa asiantuntija-asemaansa kenen tahansa lukijan silmissä. Tutkimusviittauksillaan hän toteuttaa lukuohjeessaan eksplikoimaansa periaatetta: hän osoittaa perehtyneisyyttään aihepiirin tutkimukseen ja kykyään suhteuttaa monenlaista tutkimusnäyttöä asiantuntijatyössä hankkimaansa kokemukseen ja voivansa - halutessaan - linkittää tekstiin myös aihetta koskevia tutkimusartikkeleita.

12. Ei tosin ole sanottua, että ravitsemuskeskustelussa yleisesti pidettäisiin tieteellistä tutkimusta auktoriteettina (ks. Huovila \& Saikkonen 2015: 385). 
Kirjoittaja ei viittaa vain sellaisiin tieteellisiin teksteihin, jotka tukevat hänen omaa näkemystään, vaan hän voi linkkien avulla myös haastaa tieteellistä näyttöä, kuten seuraavassa (jo edellä esitellyssä) esimerkissä:

(13) Mutta tukeeko tutkimus näitä kokemuksia? Aihepiirin tutkimus on varsin vähäistä, se vähäkin on viitteellistä ja varmasti osin siksi ilmiötä ei pidetä kovinkaan "totena". Tutkimusnäytöstä voi sanoa, että

- erilaiset mieliteot ovat naisilla hyvin selvästi miehiä yleisempiä $(1,2,3,4)$

- naisten kylläisyyden kestosta ja ateriarytmien tarpeen erilaisuudesta ei löydy juurikaan tutkimusta, joka vastaisi juuri tämän blogautuksen kysymykseen. Vain viitteellisesti nähdään satunnaisesti, että naiset tuntuvat hyötyvän miehiä enemmän erilaisista verensokeria tasaavista tekijöistä $(\mathrm{mm}$. glykeeminen kuorma 1, HH vs. Proteiini 2). Vain tutkimusta katsottaessa ilmiötä voi siis epäillä nälänhallinnan osalta ja joskus törmäänkin siihen, että asiaa pidetään urbaanina legendana. Tutkimusnäytön pohjalta sitäkin mieltä voi olla, mutta tutkimusta on aika vähän tästä aiheesta ja olen toistaiseksi eri mieltä. (16)

Esimerkin aloittava kysymys, niin sanottu pseudokysymys, implikoi mahdollisuutta, että tutkimusnäyttö ei tue kirjoittajan kokemuksia, ja myös lukijan, joka kaipaa tutkimusnäytön arviointia (ks. Martin \& White 2005: 110). Se, että kirjoittaja ylipäätään alkaa arvioida tutkimusnäyttöä, konstruoi tekstiin lukijan, jota kirjoittajan kokemus - niin taustatieto kirjoittajasta kuin tämän esittelemät kokemukset käytännön työstä - eivät riitä vakuuttamaan. Kirjoittaja arvioi kriittisesti, tukeeko tutkimusnäyttö hänen omaa väitettään (painonhallinnassa tasaisen ateriarytmin ylläpito on tärkeämpää naisille kuin miehille): arvioidessaan hän käyttää modaaliverbejä (Tutkimusnäytöstä voi sanoa ja - sitäkin mieltä voi olla) implikoiden, että näyttöä voi tulkita monella tavalla, ja luo siten tilaa myös omalle, tutkimusnäyttöön nähden vastakkaiselle näkökulmalleen (ks. mts. 105). Tutkimusnäytön vähäisyyttä ja riittämättömyyttä korostamalla kirjoittaja perustelee, miksei tutkimus näytä tukevan hänen omaa väitettään ja miksi hän on tutkimustuloksista toista mieltä: Aihepiirin tutkimus on varsin vähäistä, se vähäkin on viitteellistä - -; tutkimusta on aika vähän tästä aiheesta. Esimerkin viimeinen lause esittää kirjoittajan suhtautumisen tutkimusnäytöstä mahdollisesti tehtäviin johtopäätöksiin: olen toistaiseksi eri mieltä.

Tällä tavalla tutkimusviitteiden kanssa keskustelemalla ja tutkimusnäytön riittävyyttä evaluoimalla sekä "sanomalla viimeisen sanan" kirjoittaja asettuu asiantuntijarooliin (ks. myös Luzón 2013: 439, 451): hän nostaa oman käytännön kokemuksensa ja arviointikykynsä puuttuvan tutkimusnäytön korvaavaksi todisteeksi. Viimeisen lauseen adverbi toistaiseksi kertoo siitä, ettei kirjoittajan kanta ole kuitenkaan lopullinen, vaan hän on tilanteen vaatiessa valmis muuttamaan näkemystään. Kun hän ei esitä väitettä ehdottomana, antaa hän lukijallekin tilaa olla toista mieltä (ks. Martin \& White 2005: 103, 108-109).

Sitä vastoin vaikkapa edellä esimerkissä 4 kirjoittaja kiistää kalorien laskemisen hyödyt painonhallinnassa varsin painokkaasti ja samalla kutsuu lukijaa ottamaan sa- 
man kielteisen kannan (ks. Martin \& White 2005: 97, 118-119): Se, että alkaa syömään uudella rytmillä, uudenlaisia ruokia ja uudella ajatuksella ei liity kaloritietoon mitenkään. Se, kuinka paljon lukijalle annetaan tilaa olla kirjoittajan kanssa eri mieltä, riippuukin tekstin puheenaiheesta ja siitä, kuinka vahva kanta kirjoittajalla itsellään siihen vaikuttaa olevan.

\subsubsection{Kohdetekstinä mediateksti}

Hyperlinkkiviittaukset yleistajuisiin mediateksteihin (7 linkkiä 207:stä) voivat konstruoida asiantuntija-maallikko-asetelman, joka avaa kirjoittajalle tilaisuuden esittää oman asiantuntijanäkemyksensä vaikkapa julkisuudessa olleesta keskustelusta kuten edellä esimerkissä 9. Siinä kirjoittaja perustelee tekstinsä aihetta omalla harmistumisellaan: Mutta blogautus kuitenkin tuli, sillä vielä enemmän minua harmittaa virheellinen tieto. Myös seuraavassa Pronutritionist-blogin esimerkissä kirjoittaja ottaa valistavan asiantuntijan roolin:

(14) Harva se viikko saamme lukea kahvin terveysvaikutuksista yhtä ja toista. Välillä kahvi on terveellistä ja välillä lisää jopa ennen aikaisen kuoleman vaaraa. Tuloksien suunta riippuu siitä mitä (sairautta) on satutttu tutkimaan ja millaisella tutkimusmenetelmällä.

Tutkimustulosten ristiriitaisuus ja varsinkin tuloksista räväkästi uutisointi on monien mielestä joko ärsyttävää tai huvittavaa. - -

Mielestäni juuri ilmestynyt massiivinen kahvianalyysi jälleen kerran osoittaa sen, mikä on keskeisintä ravitsemustutkimuksessa. Ravitsemusasioissa on siedettävä pientä ristiriitaisuutta sekä ennen kaikkea nähtävä metsä puilta, asiat ovat harvoin mustavalkoisia. Kahvista löytyy hyvää ja huonoa kerrottavaa, kuten useimmista muistakin ruuista. (PN)

Esimerkki on blogitekstin alusta. Kirjoittaja pohjustaa tekstin aihetta viitaten kahteen ristiriitaiseen uutiseen kahvin terveysvaikutuksista: ensimmäinen linkki (Välillä kahvi on terveellistä) johtaa HS.fi:n ja toinen ( ja välillä lisää jopa ennen aikaisen kuoleman vaaraa) MTV.fi:n uutiseen. Kolmas linkki (juuri ilmestynyt massivinen kahvianalyysi) puolestaan ohjaa tieteelliseen artikkeliin. Uutisiin vievät hyperlinkit tuovat tekstiin median äänet, joiden välittämä näkökulma kaipaa kirjoittajan mielestä oikaisua. Viitattuaan näihin ääniin kirjoittajan on luontevaa esittää oma, korjaava näkökulmansa (vrt. Mäntynen 2003: 64-65) - tässä tapauksessa selittää lukijalle, mistä ristiriitaiselta näyttävät tutkimustulokset johtuvat.

Lukijaksi hahmottuu hämmentynyt maallikko, joka tarvitsee opastusta median välittämän ristiriitaisen tiedon tulkintaan. Kirjoittaja asettuu monikon ensimmäisellä persoonalla ensin itsekin tähän hämmentyneiden joukkoon (saamme lukea). Viidenneltä riviltä alkavassa virkkeessä hän ei kuitenkaan enää eksplisiittisesti ilmaise kuuluvansa niihin "moniin", joita tällainen ristiriitaisuus joko ärsyttää tai huvittaa. Toisin kuin esimerkissä 9, tässä kirjoittaja siis etääntyy emotionaalisesta suhtautumistavasta (ks. Martin \& White 2005: 103-104, 113-114), mitä selittää hänen seuraava argument- 
tinsa: hänen mukaansa tällaista ristiriitaisuutta on siedettävä. Argumenttinsa tueksi nostamansa tutkimuskoosteen hän esittää johtoverbillä (osoittaa) kiistämättömäksi vieden lukijaltakin tilaa olla eri mieltä (ks. mts. 103). Kirjoittajapositioon hahmottuu siten asiaan analyyttisesti ja varmasti suhtautuva asiantuntija.

\subsubsection{Kohdetekstinä blogi}

PP-blogin kirjoittaja viittaa omiin aiempiin teksteihinsä 38 kertaa ydinaineistoni kaikista 207 hyperlinkkiviittauksesta. Viitatessaan omiin teksteihinsä hän voi osoittaa omaa laaja-alaisuuttaan ja perehtyneisyyttään käsillä olevaan aiheeseen ja rakentaa siten asiantuntijarooliaan (ks. Luzón 2009: 81) kuten edellä esimerkeissä 4 ja 11. Alaluvun 2.2 lopussa siteeraamassani blogin kirjoittajaa ja tarkoitusta luonnehtivassa esittelytekstissä (s. 166) kutsutaankin blogille lukijaa, joka syömiseen liittyviin ongelmiinsa apua etsiessään voisi tutustua kirjoittajan koko tuotantoon (joskus ei vain itse pääse eteenpäin vaikka lukisi kaikki kirjani ja tekstini), ja tarjotaan tälle myös mahdollisuutta tulla vastaanotolle.

Edellä esitellyssä esimerkissä 10 (Kun luin tuossa Reijon mainion VHH-sarjan yhteenvetoa) hyperlinkki johtaa toiseen ravitsemusblogiin. Viitatessaan muiden asiantuntijoiden blogeihin (8 linkkiä 207:stä) - etenkin niiden kirjoittajien etunimellä - kirjoittajan voi tulkita osoittavan, että hän kuuluu heidän kanssaan samaan yhteisöön, ja luovan näin yhteenkuuluvuutta muiden saman alan tai aihepiirin asiantuntijoiden välille. Osa kirjoittajan asiantuntijuudesta rakentuu sen varaan, että hän on tämän yhteisön jäsen (ks. Riesch \& Mendel 2014: 62). Saman alan ja aihepiirin blogiyhteisössä blogien väliset viittaukset voivatkin olla odotuksenmukainen käytäntö (esim. Luzón 2009: 81): niiden avulla voidaan ylläpitää bloggaajien välistä keskustelua ja antaa tunnustusta aiheen tai ajatuksen alkuperäiselle keksijälle tai käsittelijälle, samoin kuin tieteellisessä viittauskäytännössä. Vaikka Rydenfeltin (2016: 220) mukaan nykypäivänä bloggaajien ei voi odottaa palvelevan linkkien avulla yhteisön rakentamista, etenkin positiiviset evaluaatiot esimerkin 10 tapaan luovat kuvaa solidaarisesta yhteisöstä (Luzón 2009: 82) - myös yhteisöön kuulumattomien silmissä.

Kun tekstin puheenaihetta kontekstualisoidaan viittaamalla johonkin pinnalla olevaan puheenaiheeseen ja mukaan liitetään linkki aihetta käsittelevään blogitekstiin tai sanomalehtiartikkeliin, puhutellaan sekä lukijaa, jolle aihe on julkisesta keskustelusta tuttu, että lukijaa, joka ei ehkä ole törmännyt kyseiseen aiheeseen mutta jolle linkki tarjoaa mahdollisuuden tutustua tähän keskusteluun.

\section{Yhteenvetoa ja päätelmiä}

Olen tässä artikkelissa tarkastellut, minkälaisia funktioita hyperlinkit saavat yleistajuisissa ja tutkittuun tietoon perustuvissa alan asiantuntijoiden kirjoittamissa terveysja ravitsemusaiheisissa blogiteksteissä ja minkälaisia kirjoittaja- ja lukijapositioita teksteille linkkien kautta hahmottuu. Aineistoesimerkkien avulla olen havainnollistanut, miten hyperlinkin perusfunktion, viittaamisen, lisäksi linkit saavat myös muita tehtäviä sen 
mukaan, minkälaiseen kielelliseen toimintaan ne asettuvat: niillä selitetään käsitteitä, tarjotaan tieteellisiä lähdeviitteitä ja tuetaan omaa argumentointia sekä kontekstualisoidaan oma teksti ympäröivään maailmaan ja ajankohtaisiin keskusteluihin.

Kirjoittaja- ja lukijapositioiden kannalta mielenkiintoisia ovat ensinnäkin blogin kynnystekstit. PP-blogin kirjoittajaa ja blogin tavoitteita esittelevän tekstin perusteella blogi on suunnattu kenelle tahansa terveellisistä elintavoista kiinnostuneelle ja erityisesti ongelmiinsa apua hakevalle lukijalle. Blogin tutkimusviittauksia koskevassa lukuohjeessa lisäksi implikoidaan, että kaikkia lukijoita eivät kiinnosta viitteet, mutta samalla tekstiin rakentuu lukija, joka odottaisi blogilta tarkkoja tieteellisiä lähdeviittauksia. Lukuisat hyperlinkkiviittaukset tieteellisiin teksteihin tuntuvatkin kutsuvan lukijapositioon asiantuntijaa tai muuten tieteellisiä lähteitä arvostavaa lukijaa. Toisaalta tutkimusviittausten voi tulkita olevan kaikille lukijoille suunnattuja; vaikka tieteellisen kohdetekstin substanssi olisikin vain asiantuntijalle tarkoitettu, voi hyperlinkin olemassaolo toimia myös maallikolle merkkinä siitä, että kirjoittaja on perehtynyt tutkimukseen. Kirjoittajapositioon hahmottuukin usein auktoriteetti, joka voi linkkien avulla osoittaa tieteellisen tutkimuksen tuntemustaan ja kykyään evaluoida ja haastaa tutkimusnäyttöä oman kokemuksensa valossa. Mediateksteihin johtavat linkit tarjoavat kirjoittajalle valistavan asiantuntijan position, kun taas toisiin blogeihin johtavien linkkien avulla hän voi ilmaista kuulumistaan asiantuntijayhteisöön. Linkit yleistajuisiin teksteihin kutsuvat etenkin maallikkolukijaa, joka kohdetekstien kautta voi paremmin hahmottaa, minkälaiseen ilmiöön tai keskusteluun käsillä oleva termi tai tekstin aihe liittyy.

Linkkinä toimivan ankkuritekstin ja sitä ympäröivän kielellisen toiminnan avulla kirjoittaja voi luoda tekstiin lukijan, joka avaa linkin ja lukee kohdetekstin tai joka sivuuttaa sen. Tieteellisen kohdetekstin lukemista ei kuitenkaan tarkastelemassani aineistossa aseteta koskaan välttämättömäksi blogitekstin ymmärtämisen kannalta, jolloin yhtenä lukijapositiona on aina maallikko. Se, miten kirjoittaja osoittaa suhtautuvansa kohdeteksteihin, luo myös lukijapositiota: aiheesta riippuen lukijalle annetaan tai ei anneta tilaa olla eri mieltä.

Artikkelissa esittelemäni tutkimustulokset tukevat aiempia, ulkomaisten ja englanninkielisten tiedeblogien hyperlinkeistä ja lukijapositioista tehtyjä havaintoja: linkit saavat moninaisia funktioita, ja yleisö voi olla kirjava (Luzón 2009, 2013; Mahrt \& Puschmann 2014; ks. myös Mauranen 2013). Yhteistä on myös havainto siitä, että blogi voi toimia kirjoittajan asiantuntijaposition vahvistamisen välineenä. On kuitenkin tiedostettava, että aktuaalisen lukijan tulkinta tekstistä voi olla eri kuin mihin kirjoittaja on tekstin tarkoittanut tai millaisen vastaanottajan hän on tekstiin konstruoinut. Siksi tässä artikkelissa esiin nousseita havaintoja olisi mielenkiintoista täydentää reseptioanalyysilla, esimerkiksi luettamalla blogitekstejä testilukijoilla tai tarkastelemalla blogin aitoja lukijakommentteja (ks. Mahrt \& Puschmann 2014): ketkä tekstejä lukevat ja miten ja miksi he niitä kommentoivat? Lisäksi hyperlinkkien vaikutusta niin tiedon esittämisen strategioihin kuin kirjoittaja- ja lukijapositioihinkin voisi tarkastella syvällisemmin vertaamalla blogitekstejä samojen asiantuntijoiden vastaavista aiheista kirjoittamiin painettuihin teksteihin: Miten esimerkiksi termien selittäminen tai tekstin aiheen kontekstualisointi tapahtuu ilman hyperlinkkejä? Entä miten painetussa tekstissä olisi mahdollista puhutella blogitekstin tavoin samalla kertaa monenlaisia lukijoita? 


\section{Lähteet}

Aarseth, Espen 1994: Nonlinearity and literary theory. - George P. Landow (toim.), Hyper/ Text/Theory s. 51-86. Baltimore, MD: Johns Hopkins University Press.

Bahtin, Minail 1986 [1953]: The problem of speech genres. - Caryl Emerson \& Michael Holqvist (toim.), Speech genres and other late essays s. 6o-102. Austin: University of Texas Press.

Bernstein, MARK 1988: The bookmark and the compass. Orientation tools for hypertext users. - Newsletter. ACM SIGOIS Bulletin archive. Vol. 9 (4) s. 34-45. https://doi. org/10.1145/51640.51645.

EISENLAUER, Volker 2013: A critical hypertext analysis of social media. The true colours of Facebook. Lontoo: Bloomsbury.

Eskelinen, Mark Ku 2002: Kybertekstien narratologia. Digitaalisen kerronnan alkeet. Nykykulttuurin tutkimuskeskuksen julkaisuja 75. Jyväskylän yliopisto.

Genet te, GérArd 1993: Paratexts. Englanniksi kääntänyt Jane E. Lewin. Cambridge: Cambridge University Press.

Giltrow, Janet - Stein, Dieter 2009: Genres in the Internet. Innovation, evolution, and genre theory. - Janet Giltrow \& Dieter Stein (toim.), Genres in the Internet. Issues on the theory of genres s. 1-25. Amsterdam: John Benjamins. https://doi.org/10.1075/ pbns.188.o1gil.

Grafton, KATHRYN 2009: Situating the public social actions of blog posts. - Janet Giltrow \& Dieter Stein (toim.), Genres in the Internet. Issues on the theory of genres s. 85-111. Amsterdam: John Benjamins. https://doi.org/10.1075/pbns.188.o4gra.

Helasvuo, Marja-Liisa - Johansson, Marjut - Tanskanen, Sanna-Kaisa 2014: Johdatus digitaaliseen vuorovaikutukseen. - Marja-Liisa Helasvuo, Marjut Johansson \& Sanna-Kaisa Tanskanen (toim.), Kieli verkossa. Näkökulmia digitaaliseen vuorovaikutukseen s. 9-28. Helsinki: Suomalaisen Kirjallisuuden Seura.

Herring, Susan C. - Kouper, Inna - Paolillo, John C. - Scheidt, Lois Ann - Tyworth, Michael - Welsch, Peter - Wright, Elijah - Yu, Ning 2005: Conversations in the blogosphere. An analysis "From the Bottom Up". - Proceedings of the Thirty-Eighth Hawai'i International Conference on System Sciences (HICSS-38). Los Alamitos: IEEE Press. http://ella.slis.indiana.edu/ herring/blogconv.pdf (13.10.2017).

Herring, Susan - Stein, Dieter - Virtanen, Tuija 2013: Introduction to the pragmatics of computer-mediated communication. - Susan Herring, Dieter Stein \& Tuija Virtanen (toim.), Pragmatics of computer-mediated communication s. 3-32. Berliini: Walter de Gruyter.

Heyd, Theresa 2009: A model for describing 'new' and 'old' properties of CMC genres. The case of digital folklore. - Janet Giltrow \& Dieter Stein (toim.), Genres in the Internet. Issues on the theory of genres s. 239-262. Amsterdam: John Benjamins. https://doi.org/10.1075/ pbns.188.10hey.

HindenmaA, Pirjo (tulossa 2018): Tekijä ja lukija tietokirjan kynnysteksteissä. - Toini Rahtu, Susanna Shore \& Mikko T. Virtanen (toim.), Kirjoitettu vuorovaikutus. Helsinki: Suomalaisen Kirjallisuuden Seura.

Hsu, Chien-leng - PARk, Han Woo 2010: Sociology of hyperlink networks of Web 1.o, Web 2.0, and Twitter. A case study of South Korea. - Social Science Computer Review 29 (3) s. 354-368. https://doi.org/10.1177/0894439310382517.

HuOvila, JANNE - SAIKKONEN, SAMPSA 2015: Establishing credibility, constructing under- 
standing. The epistemic struggle over healthy eating in the Finnish dietetic blogosphere. - Health (London) 20 (4) s. 383-40o. https://doi.org/10.1177/1363459315595849.

HylAnd, Ken 2010: Constructing proximity. Relating to readers in popular and professional science. - Journal of English for Academic Purposes 9 s. 116-127. https://doi.org/10.1016/j. jeap.2010.02.003.

JaAkola, Minna - Töyry, Maija - Helle, Merja - Onikki-Rantajä̈̈skö, Tiına 2014: Construing the reader. A multidisciplinary approach to journalistic texts. -Discourse \& Society Vol. 25 s. 640-655. https://doi.org/10.1177/o957926514536828.

Juvonen, Riıtta 2014: Näkökulma kirjoitelman dialogisuuteen. Kuinka- ja miten-yhdyslauseet ylioppilasaineessa. - Virittäjä 118 s. 73-106.

Karvonen, Pirjo 1995: Oppikirjateksti toimintana. Helsinki: Suomalaisen Kirjallisuuden Seura.

Kim, Hyo - Park, Han Woo - Thelwall, Mike 2006: Comparing academic hyperlink structures with journal publishing in Korea. A social network analysis. - Science Communication June 27 s. 540-564. https://doi.org/10.1177/1075547006288037.

Koskinen, KaISA 2014: Tunteella ja tuttavallisesti. Margot Wallströmin blogi osana Euroopan komission viestintää. - Marja-Liisa Helasvuo, Marjut Johansson \& Sanna-Kaisa Tanskanen (toim.), Kieli verkossa. Näkökulmia digitaaliseen vuorovaikutukseen s. 127-147. Helsinki: Suomalaisen Kirjallisuuden Seura.

Kouper, InNA 2010: Science blogs and public engagement with science. Practices, challenges, and opportunities. - Journal of Science Communication 9 (1) s. 1-10.

Kristeva, Julia 1993 [1967]: Sana, dialogi ja romaani. - Julia Kristeva, Puhuva subjekti. Tekstejä 1967-1993 s. 21-50. Suomentaneet Pia Sivenius, Tiina Arppe, Kirsi Saarikangas, Helena Sinervo \& Riikka Stewen. Helsinki: Gaudeamus.

LAINE, PÄIVÖ 2004: Language of interaction in online shopping. Vaasa: Universitas Wasaensis.

LANDOW, GEORGE P. 1989: The rhetoric of hypermedia. Some rules for authors. - Journal of Computing in Higher Education Spring I (1) s. 39-64. https://doi.org/10.1007/BFo2942605.

_ 1994: What's a critic to do? - George P. Landow (toim.), Hyper/Text/Theory s. 1-48. Baltimore, MD: Johns Hopkins University Press.

Linell, Per 1998: Approaching dialogue. Talk, interaction and contexts in dialogical perspectives. Amsterdam: John Benjamins.

- 2009: Rethinking language, mind, and world dialogically. Charlotte, NC: Information Age Publishing.

Luzón, María José 2009: Scholarly hyperwriting. The function of links in academic weblogs. - Journal of the American Society for Information Science and Technology 60 (1) s. 75-89. https://doi.org/10.1002/asi.20937.

2013: Public communication of science in blogs. Recontextualizing scientific discourse for a diversified audience. - Written Communication October 30 s. 428-457. https://doi. org/10.1177/0741088313493610.

Mahrt, Merja - Puschmann, Cornelius 2014: Science blogging. An exploratory study of motives, styles, and audience reactions. - Journal of Science Communication 13 (3) S. $1-17$.

Makkonen-Craig, Henna 2005: Toimittajan läsnäolo sanomalehtitekstissä. Näkökulmia suomen kielen dialogisiin passiivilauseisiin. Helsinki: Suomalaisen Kirjallisuuden Seura.

Martin, James R. - White, Peter R. 2005: The language of evaluation. Appraisal in English. Lontoo: Palgrave Macmillan.

Mauranen, Anna 2013: Hybridism, edutainment, and doubt. Science blogging finding its 
feet. - Nordic Journal of English Studies 12 (1) s. 7-36.

Miller, Carolyn R. 2014: Genre as social action (1984), Revisited 30 Years Later (2014).

- Letras \& Letras 31 (3) s. 56-72. https://doi.org/10.14393/LL63-v31n3a2015-5.

Miller, Carolyn R. - Shepherd, Dawn 2009: Questions for genre theory from the blogosphere. - Janet Giltrow \& Dieter Stein (toim.), Genres in the Internet. Issues on the theory of genres s. 263-29o. Amsterdam: John Benjamins. https://doi.org/10.1075/ pbns.188.11mil.

Morkes, John - Nielsen, Jаков 1997: Concise, SCANNABLE and objective. How to write for the web. https://www.nngroup.com/articles/concise-scannable-and-objective-how-towrite-for-the-web/ (17.10.2017).

Mänt ynen, Anne 2003: Miten kielestä kerrotaan. Kielijuttujen retoriikaa. Helsinki: Suomalaisen Kirjallisuuden Seura.

Nord, ANDREAS 2015: Positioning the reader in a polyfunctional text. Attitude and reading path in a modern Swedish handbook on gardening. - Carys Jones, Arianna Maiorani \& Sonja Starc (toim.), Meaning making in text. Multimodal and multilingual functional perspectives s. 111-133. Lontoo: Palgrave Macmillan. https://doi.org/10.1057/9781137477309_7.

Perelman, Chaїm - Olbrechts-Tyteca, Lucie 1971 [1958]: The new rhetoric. A treatise on argumentation. Englanniksi kääntänyt John Wilkinson ja Purcell Weaver. Notre Dame: University of Notre Dame Press.

PietikäInen, Sari - Mäntynen, Anne 2009: Kurssi kohti diskurssia. Tampere: Vastapaino.

Puschmann, Cornelius 2009: Lies at Wal-Mart. Style and the subversion of genre in the Life at Wal-Mart blog. - Janet Giltrow \& Dieter Stein (toim.), Genres in the Internet. Issues on the theory of genres s. 49-84. Amsterdam: John Benjamins. https://doi.org/10.1075/ pbns.188.o3pus.

_ 2013: Blogging. - Susan Herring, Dieter Stein \& Tuija Virtanen (toim.), Pragmatics of computer-mediated communication s. 83-108. Berliini: Walter de Gruyter. https://doi. org $/ 10.1515 / 9783110214468.83$.

PÖNKÄ, HARTO 2014: Sosiaalisen median käsikirja. Jyväskylä: Docendo.

Riesch, HaUke - Mendel, Jonathan 2014: Science blogging. Networks, boundaries and limitations. - Science as Culture 23 (1) s. 51-72. https://doi.org/10.1080/09505431.2013.801420.

Rydenfelt, Henrik 2016: Blogimediat ja bloggaamisen etiikka. - Media \& viestintä 39 (3) S. 209-224.

SHORE, SUSANNA 2012: Kieli, kielenkäyttö ja kielenkäytön lajit systeemis-funktionaalisessa teoriassa. - Vesa Heikkinen, Eero Voutilainen, Petri Lauerma, Ulla Tiililä \& Mikko Lounela (toim.), Genreanalyysi - tekstilajitutkimuksen käsikirja s. 131-157. Helsinki: Gaudeamus.

Strellman, Urpu - Vaat tovaAra, Johanna (toim.) 2013: Tieteen yleistajuistaminen. Helsinki: Gaudeamus.

Thompson, Geoff - Thetela, Puleng 1995: The sound of one hand clapping. The management of interaction in written discourse. - Text 1 s. 103-127.

Tү Rккӧ, JUкка 2011: Fuzzy coherence. Making sense of continuity in hypertext narrative. Helsinki: University of Helsinki.

Virtanen, Мıкко T. 2015: Akateeminen kirja-arvio moniäänisenä toimintana. Helsinki: Helsingin yliopisto.

Virtanen, Mikko T. - Juvonen, Rittta (tulossa 2018): Moniäänisyys, vuorottelu ja kerronta. Alisteisen interrogatiivilauseen sisältävät rakenteet blogivuorovaikutuksessa. - Toini Rahtu, Susanna Shore \& Mikko T. Virtanen (toim.), Kirjoitettu vuorovaikutus. Helsinki: Suomalaisen Kirjallisuuden Seura. 
Virtanen, Mikko T. - Rahtu, Toini - Shore, Susanna (tulossa 2018): Kirjoitetun vuorovaikutuksen moninaisuus ja erityisyys. - Toini Rahtu, Susanna Shore \& Mikko T. Virtanen (toim.), Kirjoitettu vuorovaikutus. Helsinki: Suomalaisen Kirjallisuuden Seura.

VISK = HaKulinen, Auli - Vilkuna, Maria - Korhonen, Rittta - Koivisto, Vesa -Heinonen, Tarja Rittta - Alho, Irja 2004: Iso suomen kielioppi. Helsinki: Suomalaisen Kirjallisuuden Seura. Verkkoversio. http://scripta.kotus.fi/visk/etusivu.php (12.10.2017).

Vološinov, Valentin 1990 [1929]: Kielen dialogisuus. Marxismi ja kielifilosofia. Suomentanut Tapani Laine. Tampere: Vastapaino.

YARos, Ronald A. 2011: Effects of text and hypertext structures on user interest and understanding of science and technology. - Science Communication 33 (3) s. 275-308. https://doi. org/10.1177/1075547010386803.

ÖHman, Jennie 2018: Interaction in text and hypertext. Participant roles on corporate websites. Åbo: Åbo Akademi University Press.

\section{Liite}

Ydinaineisto

1) 22.3.2011: Ravitsemussuositukset. http://patrikborg.blogspot.fi/2011/o7/ravitsemussuositukset.html.

2) 29.3.2011: Pitääkö mielesi nälkää? http://patrikborg.blogspot.fi/2011/o3/pitaako-mielesi-nalkaa.html.

3) 21.4.2011: Liikkumisen myötä muuttuu syömistarpeetkin. http://patrikborg.blogspot. fi/2011/o4/liikkumisen-myota-muuttuu.html.

4) 5.5.2011: Integraatiodieetti vai Hyvä Syöminen (tm)? http://patrikborg.blogspot. fi/2011/05/integraatiodieetti-vai-hyva-syominen-tm.html.

5) 19.5.2011: Kuinka usein voi syödä herkkuja? http://patrikborg.blogspot.fi/2011/05/ kuinka-usein-voi-syoda-herkkuja.html.

6) 16.7.2011: Kalorilaskenta. http://patrikborg.blogspot.fi/2011/o7/kalorilaskenta.html.

7) 4.8.2011: Säästöliekki. http://patrikborg.blogspot.fi/2011/o8/saastoliekki.html.

8) 8.12.2011: Karsiikö [sic] maku terveellisessä syömisessä? http://patrikborg.blogspot. fi/2011/12/karsiiko-maku-terveellisessa-syomisessa.html.

9) 23.1.2012: Liian hyvä syöminen. http://patrikborg.blogspot.fi/2012/o1/liian-hyva-syominen.html.

10) 14.2.2012: Onko ylipaino oma moka? http://patrikborg.blogspot.fi/2012/o2/onkoylipaino-oma-moka.html.

11) 15.3.2012: Tasainen ateriarytmi. http://patrikborg.blogspot.fi/2012/03/tasainen-ateriarytmi.html.

12) 14.5.2012: Motivoiva startti - helppo tapa sössiä muutos. http://patrikborg.blogspot. fi/2012/05/motivoiva-startti-helppo-tapa-sossia.html.

13) 6.9.2012: Riskinsieto syömisessä helpottaisi. http://patrikborg.blogspot.fi/2012/o9/ riskinsieto-syomisessa-helpottaisi.html.

14) 1.10.2012: 10 syytä nähdä kohtuuden rajat rasvaohjeissa. http://patrikborg.blogspot. 
fi/2012/10/10-syyta-nahda-kohtuuden-rajat.html.

15) 8.11.2012: Verensokerisaaga - verensokerin lasku syömisen herättäjänä. http://patrikborg.blogspot.fi/2012/11/verensokerisaaga-verensokerin-lasku.html.

16) 14.11.2012: Verensokerisaaga - tuleeko naisilla helpommin nälkä ja mielitekoja? http://patrikborg.blogspot.fi/2012/11/verensokerisaaga-tuleeko-naisilla.html.

17) 14.12.2012: Nälkävelka. http://patrikborg.blogspot.fi/2012/12/nalkavelka.html.

18) 16.1.2013: Ei alle $1500 \mathrm{kcal}$. http://patrikborg.blogspot.fi/2013/o1/ei-alle-150o-kcal. html.

19) 31.1.2013: Verensokerisaaga - miksi kovaa nälkää kannattaa välttää. http://patrikborg.blogspot.fi/2013/o1/verensokerisaaga-miksi-kovaa-nalkaa.html

20) 20.2.2013: Plasebo syömisessä. http://patrikborg.blogspot.fi/2013/o2/placebo-syomisessa.html.

21) 25.2.2013: 7 laihdutusmyyttiä murrettu - tai sitten ei. http://patrikborg.blogspot. fi/2013/02/7-myyttia-murrettu-tai-sitten-ei.html

22) 2.5.2013: Verensokerisaaga - reaktiivinen hypoglykemia eli "ensin verensokeri nousee ja sitten romahtaa". http://patrikborg.blogspot.fi/2013/05/verensokerisaaga-reaktiivinen.html.

23) 25.9.2013: Luonto, liikunta ja lihavuus - kokouksen antia. http://patrikborg.blogspot.fi/2013/og/luonto-liikunta-ja-lihavuus-kokouksen.html.

24) 2.10.2013: Mitkä ihmeen paheet? http://patrikborg.blogspot.fi/2011/12/mitka-ihmeen-paheet.html.

25) 5.12.2013: 8o/20 periaate syömisessä. http://patrikborg.blogspot.fi/2013/12/8020-periaate-syomisessa.html.

26) 23.1.2014: Kevyttuotteet. http://patrikborg.blogspot.fi/2014/o1/kevyttuotteet.html.

27) 4.2.2014: Juomisen vaikutus painoon. http://patrikborg.blogspot.fi/2014/o2/juomisen-vaikutus-painoon.html.

28) 25.2.2014: Kohti parempaa syömistä - oppia huippu-urheilun linjauksista? http:// patrikborg.blogspot.fi/2014/o2/kohti-parempaa-syomista-oppia-huippu.html.

29) 18.12.2015: Liikunta ja paino, osa 1 - asennemaailma ja pysyvän liikunnan löytäminen. http://patrikborg.blogspot.fi/2015/12/liikunta-ja-paino-osa-1-asennemaailma.html. 30) 15.2.2016: Liikunta ja paino, osa 2 - lisätyn kalorikulutuksen vaikutus. http://patrikborg.blogspot.fi/2016/o2/liikunta-ja-paino-osa-2-lisatyn.html.

\section{Vertailuaineisto}

LT = Lihastohtori 19.10.2015: Kannanottoja ajankohtaisiin terveysaiheisiin: lääkkeet, luontaistuotteet, suositukset ja asiantuntijat. https://ihastohtori.wordpress. com/2015/10/19/kannanottoja-ajankohtaisiin-terveysaiheisiin/.

PN = Pronutritionist 30.6.2016: Miten terveellistä kahvi on? 1277 tutkimusta käsittäneen analyysin tulokset kahvista -ja taas opetus ravitsemustieteestä. http://www.pronutritionist.net/2016/o6/valtavan-1277-tutkimusta-kasittaneen-analyysin-tuloksetkahvista/.

$\mathrm{RM}=$ Ruokamysteerit 13.2.2017: Vegaaniruokavalio ja syömishäiriöt. http://ruokamysteerit.fi/2017/02/13/vegaaniruokavalio-ja-syomishairiot/. 


\section{Hyperlinks: Functions, writers-in-the-text and readers-in-the-text}

The article studies what kinds of functions hyperlinks have in popular health and nutrition blog posts and what kinds of writers-in-the-text and readers-in-the-text are created through the hyperlinks. The main data consists of 30 Finnish popular blog posts written by a health and nutrition expert. Results from the main data are supported with posts written by other experts from the same field. The theoretical framework of the article is that of dialogism: language is always part of interaction, and the writer-inthe-text and the reader-in-the-text are constructed through linguistic choices within that interaction.

The article presents the types of patterned sequence of actions in which hyperlinks interact in the blog posts and what kinds of functions - besides merely referential they fulfil: they are used to provide additional information, as references to studies, to back up arguments, and to contextualise discourse topics. With the help of hyperlinks, the writer can also demonstrate belonging to a group of other experts and establish her/his position as an expert.

When analysing the readers-in-the-text of the blog posts, the focus is on the target texts behind the links: academic articles can be seen as constructing an expert reader, and popular texts a lay reader. However, the target text is not the only factor determining the reader-in-the-text, but the sequential actions surrounding the link and the anchor text construct the reader-writer relationship: to what extent does the writer guide the reader to open the hyperlink and help her/him to interpret the relevance of the target text? In addition, the paratexts of blog posts, i.e. the texts introducing the blog's aims, also create certain kinds of readers. Thus, hyperlinks that refer to academic texts can be seen to construct the authority of the writer also in the eyes of a lay reader. 


\section{Hyperlinkkien funktiot ja kirjoittaja- ja lukijapositiot}

Artikkelissa tarkastellaan hyperlinkkien funktioita yleistajuisissa ja tutkittuun tietoon perustuvissa terveys- ja ravitsemusaiheisissa blogiteksteissä sekä blogiteksteihin linkkien kautta kirjoittuvia kirjoittaja- ja lukijapositioita. Ydinaineistona on 30 suomenkielistä ja yleistajuista blogitekstiä. Ydinaineistosta tehtyjä havaintoja tuetaan vertailuaineistolla, toisten vastaavien asiantuntijoiden kirjoittamilla blogiteksteillä. Teoreettisena tausta-ajatuksena analyysissa on käsitys kielen dialogisuudesta: kielenkäyttö on aina osa vuorovaikutuksen jatkumoa, ja kielelliset valinnat ohjaavat sitä, minkälainen kirjoittaja ja lukija vuorovaikutuksessa rakentuu.

Hyperlinkkien funktioita lähestytään sen kielellisen toiminnan kautta, jonka osaksi linkit tekstissä asettuvat. Artikkelissa havainnollistetaan, miten hyperlinkin perusfunktion, viittaamisen, lisäksi linkit saavat muitakin funktioita, kuten lisätiedon tai lähdeviitteiden tarjoaminen, argumentin tukeminen sekä tekstin puheenaiheen kontekstualisoiminen. Linkkien avulla kirjoittaja voi myös osoittaa kuulumistaan muiden asiantuntijoiden kanssa samaan yhteisöön ja vahvistaa omaa asiantuntija-asemaansa.

Blogiteksteihin kirjoittuvia lukijapositioita puolestaan tarkastellaan yhtäältä linkkien kohdetekstien kautta: kun linkeillä viitataan tutkimusartikkeliin, lukijapositioon voi hahmottua asiantuntija, ja kun viitataan yleistajuiseen tekstiin, lukijaksi voi hahmottua maallikko. Toisaalta pelkästään linkin kohdeteksti ei määrittele lukijapositioita, sillä myös linkkiä ympäröivä kielellinen toiminta ja linkin ankkuriteksti rakentavat kirjoittaja-lukija-suhdetta: missä määrin kirjoittaja ohjaa lukijaa hyperlinkin avaamiseen ja auttaa kohdetekstin relevanssin tulkinnassa. Lisäksi blogitekstien kynnystekstit, kuten blogin tarkoitusta esittelevä teksti, avaavat blogille tietynlaisia lukijapositioita. Siten tieteellisiinkin teksteihin viittaavien linkkien voi tulkita vahvistavan kirjoittajan asiantuntijuutta myös maallikkolukijan silmissä.

Kirjoittajan yhteystiedot (address):

etunimi.sukunimi@helsinki.fi

ORCID: 0000-0003-4101-0718

Kirjoittaja on suomen kielen väitöskirjatutkija Helsingin yliopistossa. 